\title{
Capital Structure and Political Risk in an Emerging Market: Evidence from Companies Listed on the Stock Exchange of Mauritius
}

\author{
Lydie Myriam Marcelle Amelot (Corresponding author) \\ Department of Finance and Accounting, Faculty of Law and Management \\ University of Mauritius, Mauritius \\ E-mail: lydieamelot@yahoo.com \\ Subadar Agathee Ushad \\ Department of Finance and Accounting, Faculty of Law and Management \\ University of Mauritius, Mauritius \\ E-mail: u.subadar@uom.ac.mu \\ Mattew Lamport \\ Department of Finance and Accounting, Faculty of Law and Management \\ University of Mauritius, Mauritius \\ E-mail: m.lamport@uom.ac.mu
}

Received: July 6, 2018 Accepted: July 20, 2018 Published: July 30, 2018

doi:10.5296/ber.v8i3.13367ＵRL: https://doi.org/10.5296/ber.v8i3.13367

\begin{abstract}
Cashman, Harrison and Scheiler (2014) stated that companies with less political risk will use more debts than other organisations in other countries with more exposure to political risk. In particular, when there are low political risks, there will be more leverage and when there is high political uncertainty, there will be low debts indicating a negative relationship between financial leverage and political risk (Cashman, 2015). To this effect, this study will investigate the link between capital structure and political risk in an emerging market such as Mauritius. The data sample includes 30 financial and non- financial companies listed on the
\end{abstract}


Stock exchange of Mauritius over a time frame ranging from 2011 to 2015 with a total number of 135 observations. The political risk was based on two World Bank indicators, namely political change index and corruption perceptions index. Based on a panel regression model, the empirical results show an insignificant relationship between financial leverage and political risk. In particular, it is implied that there is little evidence on the importance of political risk on firms' decision in Mauritius due to the fact that Mauritian companies consider other types of risks to be more relevant when taking on more debts. The study adds to the existing literature on emerging markets and highlights the specificity of the Mauritian equity market relative to other developed markets.

Keywords: Capital structure, Political risk, Corruption

\section{Introduction}

Generally, companies operate in a business environment set up by government laws and regulations, policies and standards. Political decision making includes various steps that will lead to approval process. The introduction and implementation of new policies and regulations requires time, thus resulting in political uncertainty in business environments. The degree of uncertainty may be increased during times of disagreements on economic policies among policy makers. On the other hand, there is a growing literature which is focused on the implications of political connections. Empirical evidence suggests that political connections help firms to secure favorable regulatory conditions (Agrawal and Knoeber, 2001), access to resources such as bank loans (Khwaja and Mian, 2005; Fraser et al, 2006) and equity markets (Francis et al, 2009) and ultimately affect firm value or corporate performance in a variety of ways (Fisman, 2001; Johnson and Mitton, 2003; Chen et al, 2010).

However, it has still been noted that there is a lack of studies at present on the effect of political uncertaintly on firms's financing decision. Previous researchers who studied the impact of political uncertainty on corporate investment decisions found a negative effect result (Julio and Yook, 2012). Campbell and Rogers (2018) discussed about the Corporate Finance Trilemma that occurs since companies would like to decide on their debt, cash holdings, and equity payout policies at the same time, but firms cannot. According to Cao et al, (2013), there is information asymmetry between companies who borrow to finance uncertain projects and investors who lend. In fact, the model developed by Cao et al, (2013) was concentrated on Holmstrom and Tirole, (1997) credit rationing and Tirole's (2003) agent model. The model emphazized on the importance that creditors will be more rationed in lending when there are uncertainty regarding the effectiveness of a new set of government policies (Cao et al, 2013). These might have consecutive effects for instance reducing credit supplies and enhancing borrowing cost and leading to borrowing hardships. So, in this context, managers considering financial flexibility during times of high political uncertainty may result to low leverage and avoid high leverage regimes which leads us to the theory of financial flexibility hypothesis. Researchers stated that companies tend to reduce investments during periods of political uncertainty, and reduced investments potentially lead to reduced financing needs.

The purpose of the study is to investigate the impact of capital structure and political risk in 
Mauritius. As a developing country, Mauritius has become an emerging market with a lot of potential of investment that gets an attention for financial analysts, investors and financial managers need to rethink about their influencing factors of using debt and their extent of impact over companies particularly financial and non financial firms. Hence, this study will take into account the case of Mauritian financial companies listed on the Stock Exchange of Mauritius over a time period of 5 years ranging from 2011 to 2015. During this period, the Mauritian economy has passed through important transformations that have influenced almost every aspect, from political, regulatory, financial, and social factors. The importance here is to understand the main theories of finance related to capital structure and political risk measure and how it is applicable in Mauritius. Moreover, it is crucial to have a deeper understanding of this study in terms of political risk measure using the new political risk index and how it can influence the financial sector and non-financial sector based on the capital structure measures considering financial leverage. The study will also heed two controllable variables for analysis involving tangibility and size. Therefore, the technique used for analysis is concentrated on the use of panel regression analysis.

Another motive for conducting this study is that most research work performed on testing the impact of capital structure and political risk were performed mainly in developed countries including US, Canada, Asia- Pacific regions. It has to be noted that there is a lack of evidences of this study in emerging countries for instance China, Mexico. Therefore, based according to the author's knowledge, this topic is quite new in the African region as there was no studies till present in Mauritius where the theory of capital structure and political uncertainty was performed. Therefore, this would be an opportunity to bring in new evidences of this theory in relation to the African region context.

Hence, the study to be analysed is concerned with the following objectives:-

To investigate the impact of capital structure and political risk in Mauritius

To analyse the influence of capital structure and political risk and uncertainty in financial and non- financial companies in Mauritius

The plan of the study is outlined as follows: Section two provides a review of previous research studies. The research methodology and data are discussed in Section three. Section IV presents the empirical results of this study in the light of literature review and researcher's opinions. Subsequently, Section five summarizes the findings and presents the conclusion and policy implications.

\section{Literature Review}

The recent studies that were performed to analyse the impact of capital structure and political risk and the use of various types of econometric techniques and data frequencies are described to explain this theory.

La Porta et al. (1998, 2000) reported the importance of variation in the political business environment of a country in explaining the behaviors of firms, while Fatemi (1988) explained that organizations that operate across national boundaries utilize less debts. 


\section{MInstitute Macrothink $_{\text {Ins }}$}

Business and Economic Research

ISSN 2162-4860

2018, Vol. 8, No. 3

Chang and Wong (2004) examined the local political control of decision making in Chinese firms, and demonstrated that the existing level of local Party control is excessive and is negatively related with firm performance.

Faulkender and Peterson (2006) found that companies with public leverage market access had higher leverage ratios and were more likely to issue debt to those who did not have access. The results indicated that firms without public debt market access were affected more by borrowing issues imposed by political uncertainty and might encounter difficulties to increase debts during periods of high political uncertainty.

Dessai (2006) studied the impact on political risk on risky foreign investment. The evidence indicated that returns on investment in politically risky foreign countries were more volatile than returns, and multinational firms reduced their leverage in relation to the political risks they faced abroad. A one standard deviation increase in foreign political risks is related with $3.5 \%$ reduced leverage. The effect of foreign political risks on leverage was confirmed for organisations in industries whose earnings were most susceptible to political influence.

Goldman et al. (2009) identified defense and energy sectors as being subject to political risk. They reported that firms had longer underleverage effects compared to firms in other industries when political uncertainty is high. This result indicated that political uncertainty had an impact on financing decisions, and a firm's exposure to political risk increased the effect of political uncertainty on intertemporal capital structure decisions.

Dong et al (2010) examined the determinants of capital structure using 876,353 Chinese firm-year observations during the 1998-2007 period. Consistent with the results in developed markets, it was found that long-term debt ratios are positively related to firm size and asset tangibility but negative related to profitability and growth opportunities. The results stated that long-term debt ratios are positively related to state ownership and legal person institutional ownership thus suggesting that companies with more government stake were more likely to benefit long-term loans from banks.

Kesternich et al (2010) investigated how multinational firms opted the capital structure of their foreign counterparts in relation to political risk. They focused on the leverage and the ownership structure of the foreign affiliate, and they differentiated various types of political risk, such as expropriation, unreliable intellectual property rights and confiscatory taxation. Results stated that, as political risk increases, the ownership share decreases, whereas leverage can both increase or decrease, depending on the type of political risk.

Bliss et al (2011) investigated the relationship between Malaysian politically connected institutions and the cost of debt. It was found that companies had a significant relationship in terms of higher extent of debts, higher likelihood of a reporting a loss, higher negative equity and more chance of being audited by a high standard audit institution. It was recommended that PCON firms are charged by higher interest rates by lenders due to the high level of risks incurred. Moreover, it was reported that the presence of CEO duality in PCON organisations are considered to be highly risky by lending institutions.

Julio and Yook (2012) showed that corporate investment is reduced when political 
uncertainty is high.

Bliss et al (2012) analysed the relationship between Malaysian PCON firms and leverage, and found the same results of Fraser et al. (2006) who reported a positive nexus between leverage and political patronage. The results stated that market to book ratio was positively related with debts and that borrowing PCON organisations noted a significantly lower ROA compared to non- PCON companies.

Pastor and Veronesi $(2012,2013)$ examined the asset pricing implications of political uncertainty. They indicated that risk premium would increase in periods of high political uncertainty.

Cao et al (2013) examined the impact of political uncertainty in capital structure decisions. The study developed a model to show how high political uncertainty could increase borrowings and during such periods of uncertainty, companies would not employ high debts in order to be financially flexible. Therefore, the results mentioned that during periods of high political uncertainty, organisations might reduce leverage and prefer to be underleverage for longer periods and wait longer periods to issue leverage. On the other hand, it was noted that firms having low political risk and have access to public leverage were not that much sensitive to variations in political uncertainty in the determination of capital structure. It was also observed that firms held more cash during periods of high political uncertainty.

Cashman et al (2015) investigated the influence of political risk on the cost of capital for publicly traded real estate firms and property trusts across the Asia- Pacific region. The study employed three measures of political risk namely political rights index, political change index and corruption perception index. The study found that when there is a high political risk, the cost of equity and its weighted average cost of capital might increase. However, there is no significant relationship between political risk and cost of debt.

Danglu (2017) investigated the relationship between the turnover of prefecture-city officials and the risk faced by local firms in China. Data was based on a time frame of 14 years ranging from 1999 to 2012. Results indicated that official turnovers increased firm risk significantly. Moreover, the results stated that political risk was reduced when new prefecture- city officials had good connections with their provincial leaders. It was also noted that political uncertainty was more present for regulated institutions and those residing in regions where there is low market openness.

\section{Data and Methodology}

In order to investigate the impact of capital structure and political risk in Mauritius, this paper will use the Panel Regression model analysis as adapted by Cao (2013), Cashman et al (2014), Cashman et al (2015).

\subsection{Data Sample and Data Measurement}

The data sample in this study is made up of 30 companies. All the data is secondary and are collected from the financial statements, website. The data consists of 135 observations ranging from January 2011 to December 2015. 


\subsection{Research Hypotheses}

As the objective is to investigate the impact of capital structure and political risk in Mauritius, the following hypotheses for testing have been designed as follows:

$\mathrm{H}_{0^{-}}$There is no significant relationship between capital structure and political risk in Mauritius.

$\mathrm{H}_{1}$ - There is a significant relationship between capital structure and political risk in Mauritius.

\subsection{Generic Model}

Therefore, in this study, the hypothesis testing for the two variables of political risk and the two controllable variables is represented as follows:-

Financial Leverage it $=f[$ POLRit + CORit + ROAit + TANit + SIZEit $+\varepsilon t]$

Financial Leverage it refers to leverage on company $i$ at time $t$

POLRit refers to Political risk using political change index and corruption perception index on company $\mathrm{i}$ at time $\mathrm{t}$

ROAit is Return on Assets on company i at time $t$

TANit is Tangibility on company $i$ at time $t$

SIZEit is Size on company $i$ at time $t$

ept is error term

Based on the regression model, the dependent variable is Financial Leverage and the independent variables are Political Risk, Return on Asset, Tangibility and Size.

\subsection{Research Model}

According to this study, the regression model are designed as follows:-

Model 1: Capital Structure and Political Risk (Political Change Index)

FINLEVit $=\grave{\alpha}+\boldsymbol{\beta} 1$ POLRit $+\boldsymbol{\beta} 2$ ROA $+\boldsymbol{\beta} 3$ TAN $+\boldsymbol{\beta} 4$ Size $+\varepsilon t$

Where:-

$\grave{\alpha}$ is coefficient

FINLEV is financial leverage in firm $\mathrm{i}$ at time $\mathrm{t}$

POLR is political risk in firm $i$ at time $t$

ROA denotes Return on Assets in firm $\mathrm{i}$ at time $\mathrm{t}$

TAN is tangibility in firm $i$ at time $t$

Size is size in firm $\mathrm{i}$ at time $\mathrm{t}$ 
Et is error term

Model 2: Capital Structure and Political Risk (Corruption Perception Index)

FINLEVit $=\grave{\alpha}+\boldsymbol{\beta} 1$ CORit $+\boldsymbol{\beta} 2$ ROAit $+\boldsymbol{\beta} 3$ TANit $+\boldsymbol{\beta} 4$ Sizeit $+\varepsilon t$

Where:-

$\grave{\alpha}$ is coefficient

FINLEVit is financial leverage in firm $\mathrm{i}$ at time $\mathrm{t}$

COR is corruption risk in firm $i$ at time $t$

ROA denotes Return on Assets in firm $\mathrm{i}$ at time $\mathrm{t}$

TAN is tangibility in firm $\mathrm{i}$ at time $\mathrm{t}$

Size is size in firm $\mathrm{i}$ at time $\mathrm{t}$

Et is error term

\subsection{Measurement of Attributes (Companies' Specific Factors and Accounting Indicators)}

Table 1. Measurement of attributes

\begin{tabular}{|l|l|l|}
\hline Firms Specific Factors & Measurement & Source \\
\hline Financial Leverage & Total Debts / Total Assets & Financial Statements, Annual Reports \\
\hline Return on Assets & $\begin{array}{l}\text { Net Profit Afer Tax/Average } \\
\text { Total Assets *100 }\end{array}$ & Financial Statements, Annual Reports \\
\hline Political Risk - Measurement 1 & (Political Change Index) & World Bank Indicators \\
\hline Political Risk - Measurement 2 & (Corruption Perception Index) & World Bank Indicators \\
\hline Tangibility & Fixed Assets / Total Assets & Financial Statements, Annual Reports \\
\hline Size & Ln (Total Assets) & Financial Statements, Annual Reports \\
\hline
\end{tabular}

\subsection{Explanation of Variables}

(i) Political Risk Variables

Political risk can be measured in various ways including contracts, efficient government operations, business support, regulatory issues, level of corruption, political stability and ability of government institutions to appropriate property or extra payments from investors (Cashman 2015). To assess the impact of political uncertainty on capital structure decisions, a new measure of the political uncertainty index used by Cashman (2009), (2014), (2015), Cao et al (2013), Baker et al (2012) will be used. In other words, two measures will be utilized a) political change index and b) corruption perception index. The values of each of these companies' indexes reflect the average scores of the political risk exposure confronted by each firm on an annually basis. In fact, the measures may capture various aspects of political risk related to political changes that will influence the business environment and the perception of corruption that the company may face.

Firstly, the political change index analyzes political changes that may occur in a given 
country within the next 10 years that will materially and negatively affect the operational business environment. The country scores employed to calculate this index are given by the Business Risk Service through the use of Political Risk Index (PRI). The study uses a long run average of the Political change index score in Mauritius. While higher political risk index scores state a more business friendly environment with little opportunity for change, the scores are remeasured by multiplying them by negative one, and again construct the annual index value. Given the remeasurement of the PRI of the Business Risk Service, higher scores are given again.

Secondly, the political risk measure is based on the Transparency International Corruption Perception Index (TICPI). Based on the article of Cashman and Deli (2009), the study employs a long run average of the TICPI score of Mauritius and rescales the TICPI score of Mauritius by multiplying it by negative one. Similarly, firms for each year are then built by multiplying the number of firms by the remeasured TICPI score of the country. Under this approach, higher corruption perceptions index values indicate an average level of perceived corruption within the country, and hence are hypothesized to be related with greater levels of political risk exposure for the companies.

However, according to Cashman et al (2015), countries holding investment properties in jurisdictions where there is high levels of political instability use less leverage whereas when there is low risk of political instability, more debts will be employed.

(ii) Profitability

Depending on the non- financial sector expressing lower need for external financing indicating negative association whereas financial expressing the need of financing revealing a positive relationship (Anabila 2017).

(iii) Tangibility

According to empirical evidences, tangible assets tends to be more effective collateral than their intangible counterparts (Myers (1977) and (1984), Titman and Wessels (1988), Baker and Wurgler (2002). Myers (1977) stated that tangible assets support a higher level of leverage in comparison with intangible assets, namely growth opportunities. Assets can be reallocated to their intrinsic values because they are less specific and use as collateral to reduce agency costs. Therefore, there is a significant positive relationship between tangibility and capital structure.

(iv) Size

Firm size is expected to be positively related to leverage as larger firms may be more diversified, have access to capital markets easily, receive higher credit ratings for debt constraints, and pay reduced interest rates on borrowed funds (Wanjogu 2014). So, there is a significant positive relationship between size and capital structure. 


\section{1) Macrothink}

Business and Economic Research

ISSN 2162-4860 2018, Vol. 8, No. 3

\section{Results and Discussion}

\subsection{Descriptive Statistics}

Table 2 shows the descriptive statistics based on 135 observations (sample size, mean, standard deviation, minimum and maximum) for the variables considered in the analysis. The political change index is an analysis of how political changes in the country will influence business operations, and the likelihood of change happening in the next ten years. The corruption perceptions index is a metric of the perception in the level of corruption within the operational environment of a company. From the table, the mean leverage of the Mauritian market is 0.4385 , profitability accounted for 3.5987 , political risk using Political Change Index (-30.60) and Co, tangibility 0.3104 and size 16.29. The result of minimum value ranges from -51.00 to 11.56 while that of maximum value ranges from -36.29 to 22.52 respectively.

Table 2. Descriptive statistics of the study

\begin{tabular}{|c|c|c|c|c|c|c|c|c|c|}
\hline \multicolumn{10}{|c|}{ Descriptive Statistics } \\
\hline & $\mathrm{N}$ & Minimum & Maximum & Mean & Std. Deviation & \multicolumn{2}{|c|}{ Skewness } & \multicolumn{2}{|c|}{ Kurtosis } \\
\hline & Statistic & Statistic & Statistic & Statistic & Statistic & Statistic & Std. Error & Statistic & Std. Error \\
\hline FINLEV & 135 & .00 & 8.29 & .4385 & .75312 & 8.645 & .209 & 89.316 & .414 \\
\hline POLR & 135 & -30.60 & .00 & -16.8000 & 13.85401 & .374 & .209 & -1.834 & .414 \\
\hline COR & 135 & -51.00 & -36.29 & -43.8130 & 4.79659 & .177 & .209 & -.904 & .414 \\
\hline ROA & 135 & -19.98 & 39.27 & 3.5987 & 6.51557 & 1.144 & .209 & 7.873 & .414 \\
\hline TAN & 135 & .00 & .98 & .3104 & .30021 & .781 & .209 & -.683 & .414 \\
\hline SIZE & 135 & 11.56 & 22.52 & 16.2953 & 2.64361 & .639 & .209 & -.248 & .414 \\
\hline Valid $\mathrm{N}$ & 135 & & & & & & & & \\
\hline
\end{tabular}

Source: Own study

\subsection{Capital Structure and Political Risk}

\subsubsection{Results: Metric 1- Political Change Index}

Table 3. Model summary of the study using Measure 1 Capital structure and Political Risk using Political Change Index

\begin{tabular}{|l|c|r|r|r|r|}
\hline \multicolumn{5}{|c|}{ Model Summary $^{\mathbf{b}}$} \\
\hline Model & $\mathrm{R}$ & R Square & Adjusted R Square & Std. Error of the Estimate & Durbin-Watson \\
\hline 1 & $.153^{\mathrm{a}}$ & .023 & -.007 & .75564 & 1.632 \\
\hline
\end{tabular}

Source: Own study 
Table 4. Regression analysis results using Metric 1 Capital Structure and Political RiskPolitical Change Index.

\begin{tabular}{|l|c|r|r|r|r|}
\hline \multicolumn{7}{|c|}{ Coefficients $^{\mathbf{a}}$} \\
\hline \multirow{2}{*}{ Model } & \multicolumn{7}{|c|}{ Unstandardized Coefficients } & \multicolumn{2}{|c|}{ Standardized Coefficients } & \multirow{2}{*}{ Sig. } \\
\cline { 2 - 4 } & $\mathrm{B}$ & Std. Error & Beta & & \\
\hline (Constant) & .054 & .467 & & .116 & .907 \\
\hline POLR & .002 & .005 & .044 & .503 & .616 \\
\hline ROA & -.006 & .010 & -.050 & -.556 & .579 \\
\hline TAN & -.131 & .223 & -.052 & -.587 & .558 \\
\hline SIZE & .030 & .026 & .105 & 1.138 & .257 \\
\hline
\end{tabular}

Source: Own study

\subsubsection{Results: Metric 2- Corruption Perception Index}

Table 5. Summary of the study using Metric 2 Capital Structure and Political Risk: Corruption Perception Index

\begin{tabular}{|l|c|r|r|r|r|}
\hline \multicolumn{6}{|c|}{ Model Summary $^{\mathbf{b}}$} \\
\hline Model & $\mathrm{R}$ & R Square & Adjusted R Square & Std. Error of the Estimate & Durbin-Watson \\
\hline 1 & $.147^{\mathrm{a}}$ & .022 & -.009 & .75635 & 1.629 \\
\hline
\end{tabular}

Source: Own study

Table 6. Regression analysis results using Measure 2 Capital Structure and Political RiskCorruption Perception Index

\begin{tabular}{|c|c|c|c|c|c|c|}
\hline \multicolumn{7}{|c|}{ Coefficients $^{\mathrm{a}}$} \\
\hline \multirow{2}{*}{\multicolumn{2}{|c|}{ Model }} & \multicolumn{2}{|c|}{ Unstandardized Coefficients } & \multirow{2}{*}{$\frac{\text { Standardized Coefficient }}{\text { Beta }}$} & \multirow[t]{2}{*}{$\mathrm{t}$} & \multirow[t]{2}{*}{ Sig. } \\
\hline & & B & Std. Error & & & \\
\hline \multirow{5}{*}{1} & (Constant) & -.040 & .770 & & -.052 & .958 \\
\hline & COR & -.001 & .014 & -.00 & -.092 & .927 \\
\hline & ROA & -.005 & .011 & -.04 & -.503 & .616 \\
\hline & TAN & -.133 & .223 & -.05 & -.597 & .551 \\
\hline & SIZE & .030 & .026 & .10 & 1.132 & .260 \\
\hline
\end{tabular}

Source: Own study

Table 3-6 indicate the results of the multivariate analysis of the financial leverage of companies in Mauritius and political risk exposure. It is noted that the cost of debts is not influenced by political risk regardless of which measure is utilized. The results found no significant relationship between financial leverage and its exposure to political risk regardless of which metric is used. The measure was firstly focused on the political change index and secondly on the corruption perception index. While the two measures represent directly consistent with the expected hypothesis, no results are statistically and significant at accepted levels. Firstly, it is implied that there is little evidence on the importance of political risk on firms' decision in Mauritius due to the fact that Mauritian companies consider other types of 
risks to be more relevant when taking on more debts including credit risk, liquidity risk, financial and investment risk and therefore the cost of financial leverage is a function of those various risks. Moreover, the control variables fail to attain statistical significance at accepted levels. However, even though the results are insignificant, a positive relationship between financial leverage and political risk would be characterised by low levels of political instability where firms would employ more debts. In other words, according to Cashman et al (2014), he stated that political risk lowers the level of financial leverage of real estate institutions to employ. Real estate firms with less political risk use greater financial leverage on a medium that those companies having more exposure to political risk. The result are consistent with Cashman (2015), Cashman (2014), Cao et al (2013), Kersternich et al (2010) but inconsistent with Dessai (2006), Penguy (2012), Danglu (2017).

According to the results given based on the second metric, it is noted that there is a negative relationship between financial leverage and political risk using Corruption Perception Index but insignificant. However, it could be deduced that Mauritius, being a developing country, does not have a serious corruption problem and therefore it is why it is adopting less debts. If corruption is frequently present in an economy, organisations will finance themselves with greater leverage. However, Smith and Warner (1979) stated that if corruption is regularly present in an economy, companies will finance their activities with more leverage. This could be due that leverage offer investors a higher sense of ability to monitor their activities and operations and as well greater protection from expropriation by managers. This would signify a positive statistically significant association between financial leverage and political risk (corruption perception index) but for Mauritius, it is not the case.

\section{Conclusion}

The study was concerned with the investigation of the impact of the capital structure and political risk on the Mauritian financial and non- financial market. The data sample included 30 financial and non- financial companies listed on the Stock exchange of Mauritius over a time frame ranging from 2011 to 2015 with a total number of 135 observations. The political risk was based on two World Bank indicators, namely political change index and corruption perceptions index.

The main findings can be summarized as follows:-

- Based on a panel regression model using two different metrics, namely political change index and corruption perceptions index, the empirical results show an insignificant relationship between financial leverage and political risk. The results are consistent with Cao et al (2013), Cashman et al (2015) and Cashman et al (2014), Kesternich et al (2010) but inconsistent with Dessai (2006), Penguy (2012) and Danglu (2017). Consequently, these results stated that political risk is a not a material and value relevant for financial and nonfinancial companies in Mauritius.

- Even though the results are insignificant, a positive relationship between financial leverage and political risk would be given by low levels of political instability where Mauritian companies would employ more debts. 


\section{Macrothink}

Business and Economic Research ISSN 2162-4860 2018, Vol. 8, No. 3

- According to the results given based on the second metric, it is noted that there is a negative relationship between financial leverage and political risk using Corruption Perception Index but insignificant.

- No significant relationship is being found between capital structure and the controllable variables namely tangibility and size.

Overall, it is implied that there is insufficient evidence on the importance of political risk on firms' decision in Mauritius due to the fact that Mauritian companies in the financial and nonfinancial sector consider other types of risks to be more relevant when taking on more debts. Moreover, according to the Ibrahim Index of Africa Governance (IIAG), Mauritius is the first country among the 53 African countries that has the highest score (81.4) in terms of good governance, rule of law and human rights. In other words, this means that Mauritius has less political instability and as such Political Risk does not impact on corporate firms in taking decisions to take on more debts.

\section{References}

Agrawal, A., \& Knoeber, C. (2001). Do some outside directors play a political role?. Journal of Law and Economics, 44(1), 179-198. https://doi.org/ 10.1086/320271

Akey, P., \& Lewellen, S. (2017). Policy uncertainty, political capital, and firm risk-taking. SSRN Working Paper.

Anabila, A. (2017). Culture, Capital Structure, and Implications for Accounting Regulation. Journal of Corporate Accounting and Finance, 28(2), 22-44.

https://doi.org/10.1002/jcaf.22250

Baker, M., \& Wurgler, J. (2002). Market timing and capital structure. Journal of Finance, 57(2). https://doi.org/10.1111/1540-6261.00414

Baker, S., Bloom, N., \& Davis, S. (2012). Measuring economic policy uncertainty. Unpublished Working Paper. Stanford University and University of Chicago, Stanford, CA and Chicago, IL.

Campbell, G., \& Meeghan, R. (2018). Capital structure volatility in Europe. International Review of Financial Analysis, 55, 128-139. https://doi.org/10.1016/j.irfa.2017.11.008

Cao et al. (2013). Does political risk affect capital structure choices?

Cashman, G. (2015). Political Risk and the Cost of Capital in Asia-Pacific Property Markets. International real estate review.

Cashman, G. D., \& Deli, D. N. (2009). Allocating Decision Rights: Evidence from the Mutual Fund Industry. Journal of Financial Markets, 12(4), 645-671.

https://doi.org/10.1016/j.finmar.2009.04.003

Cashman, G. D., Harrison, D. M., \& Seiler, M. J. (2014a). Advisor Choice in Asia-Pacific Property Markets, Journal of Real Estate Finance and Economics, 48(2), 271-298. 


\section{Mll Macrothink}

Business and Economic Research ISSN 2162-4860 2018, Vol. 8, No. 3

Cashman, G. D., Harrison, D. M., \& Seiler, M. J. (2014b). Capital Structure and Political Risk in Asia-Pacific Real Estate Markets, Forthcoming: Journal of Real Estate Finance and Economics.

Chang, E. C., \& Wong, S. M. L. (2004). Political control and performance in China's listed firms. J. Comp. Econ. 32(4), 617-636. https://doi.org/10.1016/j.jce.2004.08.001

Chen, H. (2010). Macroeconomic conditions and the puzzles of credit spreads and capital structure. The Journal of Finance, 65(6), 2171-2212.

https://doi.org/10.1111/j.1540-6261.2010.01613.x

Danglun, L. K. C., \& Chen, L. W. (2017). Political uncertainty and firm risk in China. Review of Development Finance, 7(2), 85-94. https://doi.org/10.1016/j.rdf.2017.06.001

Dessai, M. A. (2006). Capital Structure with Risky Foreign Investment.

Fatemi, A. M. (1988). The Effect of International Diversification on Corporate Financing Policy. Journal of Business Research, 16(1), 17-30.

http://dx.doi.org/10.1016/0148-2963(88)90078

Faulkender, M., \& Peterson, M. (2006). Does the source of capital affect the capital structure? Review of Financial Studies, 19(1), 45-79. https://dx.doi:10.1093/rfs/hhj003

Francis, B., Hasan, I., \& Sun, X. (2009). Political connections and the process of going public: evidence from China.

Fraser, D., Zhang, H., \& Derakshid, Z. (2006). Capital structure and political patronage: the case of Malaysia. Journal of Banking and Finance, 30(4), 1291-1308.

https://doi.org/10.1016/j.jbankfin.2005.05.008

Goldman, E., Rocholl, J., \& So, J. (2009). Do politically connected boards affect firm value?. Review of Financial Studies, 22(6), 2331-2360. https://doi.org/10.1093/rfs/hhn088

Holmstrom, B., \& Tirole, J. (1997). Financial intermediation, loanable funds, and the real sector. Quarterly Journal of Economics, 112(3), 663-691.

https://doi.org/10.1162/003355397555316

Ibrahim Index 2017. Online

http://www.govmu.org/English/News/Pages/Mo-Ibrahim-Index-2017-Mauritius-ranked-Firstin-Overall-Governance-in-Africa.aspx (Accessed on $20^{\text {th }}$ June 2018)

Johnson S., \& Mitton, T. (2003). Cronyism and capital controls: evidence from Malaysia. Journal of Financial Economics, 67(2), 351-382.

https://doi.org/10.1016/S0304-405X(02)00255-6

Julio, B., \& Yook, Y. (2012). Corporate financial policy under political uncertainty: International evidence from national elections. Journal of Finance, 67(1), 45-84. https://doi.org/10.1111/j.1540-6261.2011.01707.x

Kesternich, I, (2010). Who is afraid of political risk? Multinational firms and their choice of 
capital structure. Journal of International Economics, 82(2).

https://doi.org/10.1016/j.jinteco.2010.07.005

Khwaja A., \& Mian, A. (2005). Do lenders favor politically connected firms? Rent provision in an emerging financial market. Quarterly Journal of Economics, 120(4), 1371-1411. https://doi.org/10.1162/003355305775097524

La Porta, R.., López-de-Silanes, F., Shleifer, A., \& Vishny, R. W. (2000). Investor protection and corporate governance. Journal of Financial Economics, 58(1-2), 3-27.

https://doi.org/10.1016/S0304-405X(00)00065-9

La Porta, R.., López-de-Silanes, F., Shleifer, A., \& Vishny, R.W. (1998). Law and Finance, Journal of Political Economy, 106(6), 1113-1155. http://dx.doi.org/10.1086/250042

Ling, D. C., Naranjo, A. \& Giacomini, E. (2014). Leverage and Returns: A Cross-Country Analysis of Public Real Estate Markets. University of Florida Working Paper.

Pastor, L., \& Veronesi, P. (2012). Uncertainty about government policy and stock prices. Journal of Finance, 67(4), 1219-1264. https://doi.org/10.1111/j.1540-6261.2012.01746.x

Pastor, L., \& Veronesi, P. (2013). Political uncertainty and risk premia. Journal of Financial Economics, 110(3), 520-545. https://doi.org/10.1016/j.jfineco.2013.08.007

Titman, S., \& Wessels, R. (1988). The determinants of capital structure choice. Journal of Finance, 43(1), 1-19. https://doi.org/10.1111/j.1540-6261.1988.tb02585.x

Wanjogu (2014). The relationship between market power and capital structure of companies listied in the Nairobi Securities Exchange.

\section{Copyright Disclaimer}

Copyright for this article is retained by the author(s), with first publication rights granted to the journal.

This is an open-access article distributed under the terms and conditions of the Creative Commons Attribution license (http://creativecommons.org/licenses/by/3.0/). 